\title{
STRATEGI PENGELOLAAN KEBUN BINATANG BANDUNG DALAM MENGHADAPI TANTANGAN NEW NORMAL
}

\author{
AFIFA MAGFHIRA SUHERLAN1', RIZKY MUHAMMAD ILHAM ${ }^{2}$, LIA WARLINA ${ }^{3}$ \\ Universitas Komputer Indonesia1,2,3 \\ amagfhiras@mahasiswa.unikom.ac.id ${ }^{1}$ \\ rizkyotu@mahasiswa.unikom.ac.id² \\ lia.warlina@email.unikom.ac.id ${ }^{3}$
}

\begin{abstract}
Bandung has many tourist attractions and can educate the public when visiting the Bandung Zoological Garden (BAZOGA) or also known as the Bandung Zoo. The zoo is one of the ex-situ conservation institutions that must pay attention to animal welfare by meeting all minimum welfare standards. This conservation area is located in the Coblong sub-district and has an area of 13 hectares and the diversity of animals in it. The function of the zoo that provides various types of trees in urban areas can be the lungs of the city. The purpose of this study is to find out what strategies to deal with the new normal at Bandung Zoo. The research method used is to collect primary and secondary data. Primary data were obtained by direct observation of the Bandung Zoo. The analytical method used in this research is a SWOT analysis. The results of this study are the identification of the potential and problems of the Bandung Zoo. Potentials owned by the Bandung Zoo include: (1) the existence of several new animal collections, namely native African animals, (2) a new bird aviary area that allows tourists to interact directly with birds. The weaknesses of the Bandung Zoo are: (1) ticket sales have not been made online or computerized, (2) there are still many empty reptile animal collections, (3) food courts are temporarily closed during the New Normal era. The strategy to manage Bandung Zoo tourism in the New Normal period as follows. First, ticket purchases are available using an online ticket booking system or online or computerized ticket buyer. Secondly, the management creates the reptile area so that it will increase knowledge in animal knowledge and add to the collection of animals in the Bandung Zoo. Thirdly the zoo applies a non-cash payment system and regulates seating positions in the foodcourt area.
\end{abstract}

Key Words : New Normal, SWOT, Zoo

\section{ABSTRAK}

Kota Bandung memilikit tempat wisata yang cukup besar dan bisa mengedukasi masyarakat ketika berkunjung yaitu Bandung Zoological Garden (BAZOGA) atau biasa disebut Kebun Binatang Bandung. Kebun Binatang merupakan salah satu lembaga konservasi ex-situ yang harus memperhatikan kesejahteraan satwa dengan memenuhi seluruh standar minimum kesejahteraannya. Kawasan konservasi ini berada di kecamatan Coblong dan memiliki luas \pm 13 hektar serta keragaman satwa di dalamnya. Fungsi kebun binatang yang menyediakan beragam jenis pepohonan di perkotaan dapat menjadi paru-paru kota. Tujuan dari penelitian ini adalah untuk mengetahui strategi apa dalam menghadapi new normal di Kebun Binatang Bandung. Metode penelitian yang dilakukan adalah dengan mengumpulkan data primer dan sekunder. Data primer diperoleh dengan observasi langsung ke Kebun Binatang Bandung. Metode analisis yang digunakan penelitian ini adalah analisis SWOT. Hasil dari penelitian ini adalah teridentifikasinya potensi serta permasalahan yang dimiliki oleh Kebun Binatang Bandung. Potensi yang dimiliki kebun Binatang Bandung diantara lain : (1)adanya beberapa koleksi satwa baru yaitu satwa asli afrika, (2)area bird aviary baru yang memungkinkan wisatawan berinteraki secra langsung dengan burung. Adapun kelemahan yang dimiliki oleh 
Kebun Binatang Bandung yaitu : (1)penjualan tiket belum dilakukan secara online atau komputerisasi, (2)masih banyaknya koleksi hewan reptile yang kosong, (3)foodcourt ditutup sementara pada saat era New Normal. Strategi dalam pengelolaan wisata Kebun binatang Bandung dalam masa New Normal ini adalah berikut ini. Pertama, perlu disediakan pembelian tiket dengan sistem pemesanan tiket secara online atau pembelin tiket secara online maupun komputerisasi. Kedua, dengan mengisi kekosogan area reptile sehingga memperbanyak ilmu dalam penetahuan hewan dan menambah koleksi satwa yang ada di Kebun Binatang Bandun. Ketiga, dengan memberlakukan sistem pembayaran non-tunai dan mengatur posisi tempat duduk di area foodcourt.

Kata Kunci: Kebun Binatang, New Normal, SWOT

\section{PENDAHULUAN}

\section{Latar Belakang}

Komoditas yang dibutuhkan setiap individu salah satunya adalah pariwisata. Karena aktivitas pariwisata dapat menghilangkan kejenuhan kerja, meningkatkan daya kreatif, relaksasi, mengetahui peninggalan sejarah dan budaya suatu etnik tertentu. Pariwisata juga merupakan sektor ekonomi yang penting di Indonesia

Indonesia memiliki puluhan tempat wisata yang menakjubkan. Salah satunya terletak di Provinsi Jawa Barat. Banyak tempat wisata yang memiliki daya tarik tersendiri. Seperti di Kota Bandung terdapat tempat wisata yang cukup besar dan bisa mengedukasi masyarakat ketika berkunjung yaitu Bandung Zoological Garden (BAZOGA) atau biasa disebut Kebun Binatang Bandung. Kebun Binatang merupakan salah satu lembaga konservasi ex-situ yang harus memperhatikan kesejahteraan satwa dengan memenuhi seluruh standar minimum kesejahteraannya. Kawasan konservasi ini berada di kecamatan Coblong dan memiliki luas 14 hektar serta keragaman satwa di dalamnya. Fungsi kebun binatang yang menyediakan beragam jenis pepohonan di perkotaan dapat menjadi paru-paru kota.

Sebanyak 800 individu dari kelas aves, ikan, reptil \& mamalia dimiliki oleh BAZOGA. Interaksi dengan para satwa di kebun binatang bandung tidak sebatasa hanya memberikan pakan dan perawatan kesehatan saja tetapi juga pada pertunjukan satwa. Bahkan para pengunjung bisa berinteraksi dengan beberapa koleksi satwa yang ada di kebun binatang bandung, maka dari itu pihak kebun binatang bandung telah menyediakan fasilitas berfoto dengan koleksi satwa pada spot tertentu [1].

Ketika adanya pandemi yang sedang terjadi di seluruh dunia yaitu menyebarnya Corona Virus Desease-19. Pariwisata mengalami penurunan yang sangat luar biasa. Banyak tempat wisata memutuskan untuk tutup sementara sampai kondisi kembali normal. Dalam upaya pencegahan penyebaran COVID-19, Kebun Binatang Bandung juga menutup sementara akses untuk berkunjung demi memutus mata rantai penyebaran virus tersebut.

Semenjak ditutup sementaranya objek wisata Bandung Zoological Garden (BAZOGA) tentunya terdapat permasalahan yang dihadapi pihak pengelola Bandung Zoological Garden seperti pemasukan yang menurun drastis. Meskipun demikian di media sosial resmi milik Kebun Binatang Bandung, diumumkan telah menerima kunjungan wisatawan mulai 27 Juni 2020 (Gambar 1).

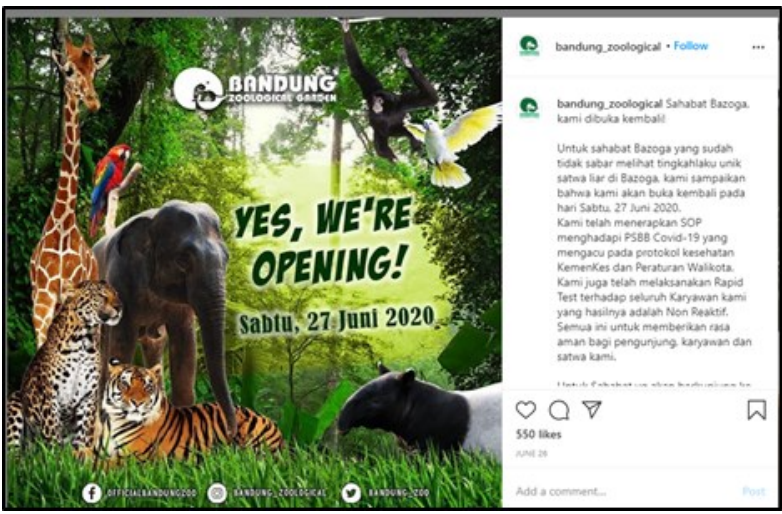

Gambar 1. Instagram Kebun Binatang Bandung menyatakan mulai buka kembali 27 Juni 2020

Permasalahan berkaitan dengan pandemi dibidang pariwisata antara lain adalah belum ada standar dalam perencanaan, pelaksanaan, pengelolaan dan pengendalian dampak pandemi di sektor pariwisata [2]. Hal ini menyebabkan banyak industri pariwisata yang mengalami kesulitan, seperti halnya Kebun Binatang Bandung. Oleh karena itu penelitian tentang Strategi Kebun Binatang 
Bandung Dalam Menghadapi Tantangan New Normal dapat diterapkan untuk menghadapi kondisi darurat seperti wabah Covid-19.

\section{Tujuan Penelitian}

Tujuan dari penelitian ini adalah untuk mengetahui strategi apa dalam menghadapi new normal di Kebun Binatang Bandung dengan sasaran sebagai berikut (1) Teridentifiksi potensi dan permasalahan untuk

menghadapi new normal yang ada di Kebun Binatang Bandung dan (2) Teridentifikasi strategi pengelolaan Kebun Binatang Bandung di masa new normal.

\section{TINJAUAN PUSTAKA}

\section{Kebun binatang sebagai salah satu atraksi wisata}

Secara garis besar definisi dari Pariwisata yaitu perjalanan dari satu tempat ke tempat lain, yang sifatnya hanya sementara, dilakukan secara berkelompok maupun perorangan sebagai usaha mencari keserasian atau keseimbangan dan kebahagiaan dengan lingkungan hidup dalam dimensi social, ilmu, alam dan budaya. Pariwisata adalah aktivitas wisata dengan berbagai macam dilakukan oleh sekelompok orang atau seseorang dan didukung oleh berbagai fasilitas serta layanan yang disediakan masyarakat, pengusaha, pemerintah dan Pemerintah Daerah [3].

Kebun binatang adalah salah satu objek wisata. Kebun binatang sebagai atraksi wisata dengan jelas mencerminkan hubungan antara manusia dan hewan dalam masyarakat. Banyak kebun binatang berubah agar memiliki tingkat daya tarik yang lebih tinggi dan untuk mendapatkan lebih banyak pengunjung. Kebun binatang ini semakin bergeser ke arah taman hiburan dengan menghadirkan banyak tema lain selain hewan. Fakta bahwa di masa lalu beberapa kebun binatang besar saat ini berukuran lebih kecil dan melalui proses tertentu. Penelitian tentang kebun binatang dan kaitannya dengan studi pada bidang pariwisata jarang dilakukan. Topik penelitian lebih banyak yang terkait dengan kebun binatang dan pariwisata misalnya tren komersialisasi, pariwisata berkelanjutan, perilaku pengunjung, atau motivasi mereka untuk mengunjungi kebun binatang. Informasi proporsi pengunjung kebun binatang yang terdiri dari wisatawan dan berapa banyak dari mereka adalah penduduk setempat merupakan aspek menarik [4].

\section{Analisis SWOT}

Analisis SWOT adalah salah satu metode untuk memproyeksikan kondisi serta berguna untuk mengevaluasi suatu masalah, proyek atau konsep bisnis yang memiliki 2 faktor yaitu faktor internal (dalam) dan faktor eksternal (luar) yaitu Strengths, Weakness, Opportunities dan Threats, maka dari itu analisis SWOT adalah sebuah analisis yang akan menghasilkan output berupa arahan dan tidak memberikan solusi ajaib dalam sebuah permasalahan.

Analisis SWOT adalah identifikasi berbagai faktor secara sistematis untuk merumuskan strategi perusahaan. Analisis ini didasarkan pada logika yang dapat memaksimalkan kekuatan (strength) dan peluang (opportunity), namun secara tidak langsung dapat meminimalkan kelemahan (weakness) dan ancaman (threats). Proses pengambilan keputusan strategi selalu disertai dengan pengembangan misi, tujuan, strategi dan kebijakan perusahaan. Maka dari itu, perencanaan strategi harus mempertimbangkan dan menganalisa faktor faktor strategi perusahaan (kekuatan, kelemahan, peluang dan ancaman) dalam kondisi yang saat ini sedang di alami [5]. Analisis SWOT juga membandingkan antara faktor eksternal peluang dan ancaman dengan faktor internal kekuatan dan kelemahan. Lalu faktor internal dimasukan kedalam matrik yang disebut matrik faktor strategi internal atau IFAS (Internal Strategic Factor Analisis Summary). Faktor eksternal dimasukkan kedalam matrik yang disebut matrik faktor strategi eksternal EFAS (Eksternal Strategic Factor Analisis Summary). Pada pengelolaan wisata beberapa penelitian menggunakan analisis SWOT untuk menyusun strategi yaitu di Tomohon dan di Minahasa Utara [6], [7].

\section{Covid-19 dan Era New Normal pada sektor pariwisata}

Coronavirus atau virus corona atau COVID-19 (Corona Virus Disease 2019) merupakan keluarga besar virus yang menyebabkan infeksi saluran pernapasan atas ringan hingga sedang, seperti penyakit flu, Infeksi virus Corona pertama kali ditemukan di kota Wuhan, China pada akhir Desember 2019. Virus ini menular dengan sangat cepat dan telah menyebar ke hampir semua negara, termasuk Indonesia, hanya dalam waktu beberapa bulan. Hal tersebut membuat beberapa negara menerapkan kebijakan untuk memberlakukan lockdown dalam rangka memutus mata rantai penyebaran virus Corona. Di Indonesia sendiri, pemerintah memberlakukan kebijakan Pembatasan Sosial Berskala Besar (PSBB) untuk menekan 
penyebaran virus ini [8].

Virus yang bersifaat zoonosis ini merupakan penyakit yang dapat menular ari hewan ke manusia seperti malaria, rabies, MERS. Selain menyerang system pernafasan vrus corona juga dapat menimbulkan penyakit yang lebih serius diantaranya Middle East Respiratory Syndrome (MERS-CoV), Severe Acute Respiratory Syndrome (SARS-CoV), dan Pneumonia. Baru-baru ini, virus corona baru muncul dan dikenal sebagai COVID-19 memicu wabah di Cina pada akhir Desember 2019, dan semakin meluas di berbagai negara sehingga WHO (World Health Organization) mendeklarasikannya sebagai pandemi global.

Penyebaran COVID 19 menimbulkan kepanikan di kalangan masyarakat yang berkontribusi pada tren penurunan industri pariwisata. Dampak COVID-19 terhadap industri pariwisata dengan menggunakan kurva permintaan dan penawaran menunjukkan penurunan fungsi permintaan menyebabkan penurunan harga dan kuantitas yang ditawarkan dalam industri pariwisata [9].

\section{METODE}

Waktu yang digunakan untuk melakukan penelitian ini adalah pada bulan Juni hingga bulan Juli 2020. Lokasi penelitian ini bertepat di Bandung Zoological Garden (BAZOGA), yang beralamat di Kelurahan Lebak Siliwangi, Kecamatan Coblong, Kota Bandung.Dalam penelitian ini penulis menggunakan jenis penelitian kualitatif dengan pendekatan deskriptif. Tahapan penelitian yang akan dilakukan terbagi atas beberapa tahapan meliputi persiapan, survey awal (pendahuluan), survey data primer \& sekunder. Memperoleh data yang relevan dan dapat dipercaya kebenarannya seperti data primer di lalui dengan cara observasi langsung ke Bandung Zoological Garden (BAZOGA) pada tanggal 27 Juni 2020. Sedangkan data sekunder yang dibutuhkan diperoleh dari lembaga atau instansi yang berhubungan dengan penelitian ini seperti Dinas Pariwisata, Yayasan Margasatwa Tamansari, serta laporan-laporan dan jurnal penelitian internet yang berhubungan dengan penelitian ini.

\section{HASIL DAN PEMBAHASAN}

Banyak tantangan yang dihadapi oleh pengelola kebun binatang di Indonesia. Salah satunya Taman Margasatwa Ragunan memiliki SOP dalam penerapan kebijakannya di era new normal, yaitu: pembatasan jumlah pengunjung yang dikhususkan untuk warga DKI Jakarta saja dengan kuota 1000 orang perhari, dilakukan system booking untuk pembelian tiket dengan syarat menggunakan KTP DKI Jakarta dan akan otomatis terkunci apabila kuota 1000 pengunjung terpenuhi, pembatasan jam operasional Kebun Binatang Ragunan yang pada mulanya buka pukul 07.30 16.00 menjadi buka pukul 08.00 - 13.00, membatasi umur pengunjung yang ingin memasuki kebun binatang ragunan dengan ketentuan umur 0 - 9 tahun dan diatas 60 tahun dilarang berkunjung ke kebun binatang ragunan, mengikuti arah petunjuk yang ditetapkan dalam area Ragunan, lalu Kebun Binatang Ragunan menyediakan keset disinfektan untuk membersihkan alas kaki para pengunjung, jika pengunjung memiliki riwayat penyakit (misalnya diabetes) maka sebaiknya tidak berkunjung ke Kebun Binatang Ragunan [10].

Berbeda hal nya dengan kebun binatang Ragunan, Taman Satwa Taru Jurug Surakarta atau biasa disebut Kebun Binatang Solo melakukan penyemprotan cairan disinfektan ke setiap kandang terlebih dahulu serta menyemprotkan cairan disinfektan di area loket tiket dan parkir, di wahana bermain anak, di besi area antrian wisatawan. Tidak sampai hanya disitu pengelola kebun binatang solo melakukan pembatasan pengunjung yang terbagi menjadi dua sesi, sesi pertama pada jam 09.00 12.00 dan sesi kedua pada jam 13.00 - 16.00, setiap sesi dibatasi hanya 500 pengunjung. Lalu memberlakukan sistem E-Ticketing bagi para wisatawan, apabila pengunjung belum memiliki $E$ Ticketing maka pengelola Kebun Binatang Solo sudah menyiapkan loket tiket berbasis komputer [11].

Industri pariwisata merupakan salah satu industri yang terkena dampak dari adanya pandemic Covid-19. Kemudian protokol tempat kerja ditemukan dalam Keputusan Menteri Kesehatan No. HK.01.07 / MENKES / 328/2020 tanggal 20 Mei 2020 tentang Pedoman Mitigasi dan Pengendalian Penyakit Coronavirus (COVID-19) di Kantor dan Pengaturan Tempat Kerja Industri dalam Upaya untuk Mendukung Kelanjutan Bisnis selama Pandemi [12]. Bilamana pengelola Kebun Binatang Bandung memiliki strategi yang mumpuni dalam menghadapi tantangan new normal tidak menutup kemungkinan industri pariwisata khususnya Kebun Binatang Bandung dapat berkembang kembali seiring berjalannya new normal. Berikut beberapa strategi yang dapat diterapkan Kebun Binatang Bandung dalam menghadapi tantangan new normal yang disajikan pada Tabel 1. 
Tabel 1. Tabel Strategi SWOT Bandung Zoological Garden (BAZOGA)

\begin{tabular}{|c|c|c|}
\hline & KEKUATAN (S) & KELEMAHAN (W) \\
\hline & $\begin{array}{l}\text { 1. Koleksi satwa baru yaitu } \\
\text { beberapa hewan asli Afrika } \\
\text { 2. Area bird aviary yang baru } \\
\text { 3. Perbaikan sarana dan } \\
\text { prasarana } \\
\text { 4. Merupakan anggota PKBSI }\end{array}$ & $\begin{array}{l}\text { 1. Wahana permainan di tutup } \\
\text { sementara } \\
\text { 2. Masih adanya display } \\
\text { hewan reptil yang kosong } \\
\text { 3. Food court di tutup } \\
\text { sementara } \\
\text { 4. Penjualan tiket secara on } \\
\text { the spot }\end{array}$ \\
\hline PELUANG (0) & STRATEGI S-O & STRATEGI W-O \\
\hline $\begin{array}{l}\text { 1. Kemajuan teknologi yang } \\
\text { dapat dimanfaatkan untuk } \\
\text { media promosi } \\
\text { 2. Peningkatan minat wisata } \\
\text { untuk berkunjung ke objek } \\
\text { wisata yang bertemakan } \\
\text { back to nature }\end{array}$ & 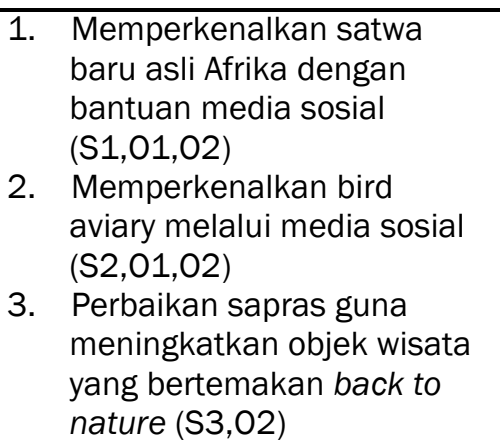 & $\begin{array}{ll}\text { 1. } & \text { Mempromosikan koleksi } \\
\text { hewan reptile di social } \\
\text { media (W2,01) } \\
\text { 2. Memfokuskan wisatawan } \\
\text { dengan koleksi satwa yang } \\
\text { ada(W1,W2,W3,02) }\end{array}$ \\
\hline ANCAMAN (T) & STRATEGI S-T & STRATEGI W-T \\
\hline $\begin{array}{l}\text { 1. Pembatasan jumlah } \\
\text { pengunjung } \\
\text { 2. Pengurangan pemberian } \\
\text { pakan hewan } \\
\text { 3. Banyaknya penjualan di } \\
\text { Kebun Binatang secara } \\
\text { online }\end{array}$ & $\begin{array}{ll}\text { 1. } & \text { Pembuatan marking } \\
\text { disetiap kandang untuk } \\
\text { menjaga jarak }(\mathrm{S} 3, \mathrm{~T} 1, \mathrm{~T} 2) \\
\text { 2. } & \text { Penggalangan dana } \\
\text { bersama PKBSI untuk } \\
\text { membantu pemberian } \\
\text { pakan hewan }(\mathrm{S} 4, \mathrm{~T} 2)\end{array}$ & $\begin{array}{l}\text { 1. Menyediakan tempat cuci } \\
\text { tangan dan hand sanitizer } \\
\text { (W1,W3,T1) } \\
\text { 2. Menyediakan metode } \\
\text { pembayaran non-tunai di } \\
\text { food court (W3,T3) } \\
\text { 3. Menyediakan jasa booking } \\
\text { tiket secara online (W4,T3) }\end{array}$ \\
\hline
\end{tabular}

\section{Formulasi strategi}

\section{Strategi S-O}

Strategi S-O diterapkan untuk memanfaatkan kekuatan Kebun Binatang Bandung guna menangkap peluang yang dimilikinya. Strategi ini dapat berjalan dengan baik jika Kebun Binatang Bandung memiliki divisi khusus untuk mengelola sosial media guna menyebarkan informasi yang akan disampaikan, serta melakukan beberapa perbaikan yang dilakukan pihak pengelola kebun binatang Bandung dalam hal sarana dan prasarana guna menambah kenyamanan satwa dan pengunjung.

\section{Strategi S-T}

Strategi S-T diterapkan dengan mencari kekuatan yang dimiliki Kebun Binatang Bandung yang digunakan untuk dapat menangkal ancaman tersebut. Strategi ini dapat terealisasi dengan baik jika para pengunjung mengikuti instruksi atau arahan yang diberikan pihak pengelola Kebun Binatang Bandung untuk berada di area marking pada saat melihat koleksi satwa. Penggalangan dana yang dilakukan Kebun Binatang Bandung Bersama PKBSI melalui media sosial merupakan cara untuk membantu dalam pengadaan pakan satwa. Bila hal ini dilakukan, maka Kebun Binatang Bandung dapat mengantisipasi ancaman dimana selama new normal. 


\section{Strategi $W-O$}

Strategi W-O dilakukan pada saat peluang yang dimiliki Kebun Binatang Bandung digunakan untuk mengurangi kelemahan Kebun Binatang Bandung. Strategi ini dapat terlaksana jika pihak pengelola menyediakan pemandu wisata untuk memfokuskan para pengunjung melihat koleksi satwa yang ada, walaupun ada wahana bermain, tempat berkumpul, dan kegiatan rekreasi lainnya yang dapat memiliki kontribusi yang besar terhadap hiburan masyarakat akan tetapi pada era new normal seperti ini wahana bermain justru ditutup sementara guna memutus mata rantai penyebaran covid-19 [13], maka dari itu wahana bermain tidak lagi berkontribusi dalam hiburan masyarakat. serta dengan masih kosongnya beberapa hewan reptile maka pengelola sebaiknya menggunakan media sosial untuk menggantikan keberadaan hewan reptile yang tidak tersedia.

\section{Strategi W-T}

Strategi W-T diterapkan saat Kebun Binatang Bandung harus mampu mengatasi kelemahan yang dimiliki agar terhindar dari ancaman new normal yang sedang dihadapi. Kebun Binatang Bandung harus mampu mencukupi kebutuhan wisatawan yang menjadi standar protokol kesehatan.

\section{KESIMPULAN}

Potensi yang dimiliki oleh Kebun Binatang Bandung menjadi daya tarik para wisatawan yang berkunjung ke Kota Bandung. Hal ini menjadikan masa pemberlakuan era new normal harus lebih diperhatikan dari segi protokol kesehatan. Strategi yang ditawarkan setelah mengkaji analisis SWOT akan dapat bermanfaat untuk menetapkan pilihanpilihan strategi dalam memahami potensi-potensi yang dimiliki pengelola Kebun Binatang Bandung untuk dapat bertahan di era new normal. Mengingat kesehatan pengunjung objek wisata sangat penting untuk diperhatikan.

Kebun binatang bandung harus bisa mengadopsi berbagai SOP yang belum di terapkan di kebun binatang bandung dari berbagai kebun binatang yang ada di indonesia terkait tantangan NEW NORMAL guna mengembangkan sektor pariwisata khususnya kebun binatang bandung.

\section{UCAPAN TERIMA KASIH}

Ucapan terima kasih disampaikan kepada Bandung Zoological Garden (BAZOGA) serta semua pihak yang telah berperan dalam penelitian strategi kebun binatang bandung dalam menghadapi tantangan new normal sehingga penerapan menghadapi New Normal ini dapat dituangkan dalam bentuk tulisan dan diinformasikan kepada para wisatawan di Indonesia.

\section{DAFTAR PUSTAKA}

[1] Bandung Zoo, "Bandung Zoo (About Us)," Bandung Zoo (About Us), 2020. http:// www.bandung-zoo.com/about-us.

[2] I. D. G. Sugihamretha, "Respon Kebijakan: Mitigasi Dampak Wabah Covid-19 Pada Sektor Pariwisata," J. Perenc. Pembang. Indones. J. Dev. Plan., vol. 4, no. 2, pp. 191206, Jun. 2020, doi: 10.36574/ jpp.v4i2.113.

[3] L. J. Lickorish and C. L. Jenkins, An introduction to tourism. Oxford; New York: Butterworth-Heinemann, 1997.

[4] L. Nekolný and D. Fialová, "Zoo Tourism: What Actually Is a Zoo?," Czech J. Tour., vol. 7, no. 2, pp. 153-166, Dec. 2018, doi: 10.1515/cjot-2018-0008

[5] E. Gürel, "SWOT Analysis: A Theoretical Review," J. Int. Soc. Res., vol. 10, no. 51, pp. 994-1006, Aug. 2017, doi: 10.17719/ jisr.2017.1832.

[6] S. A. Menajang, J. A. F. Kalangi, and D. D. S. Mukuan, "Strategi Pengelolaan Pariwisata Pinus Lahendong Di Kota Tomohon," J. Adm. Bisnis, vol. 8, no. 1, pp. 87-97, Mar. 2019, doi: 10.35797/jab.8.1.2019.23504.87-97.

[7] J. . Lengkong, L. C. Mandey, and C. R. Ngangi, "Strategi Pengembangan Kawasan Wisata Likupang Kabupaten Minahasa Utara," AgriSosioEkonomi, vol. 14, no. 1, p. 425, Jun. 2018, doi: 10.35791/ agrsosek.14.1.2018.19727.

[8] E. Guridno and A. Guridno, "Covid-19 Impact: Indonesia Tourism in New Normal Era," Int. J. Manag. Humanit., vol. 4, no. 11, pp. 31-34, Jul. 2020, doi: 10.35940/ 
ijmh.K1049.0741120.

[9] N. A. Bakar and S. Rosbi, "Effect of Coronavirus disease (COVID-19) to tourism industry," Int. J. Adv. Eng. Res. Sci., vol. 7, no. 4, pp. 189-193, 2020, doi: 10.22161/ ijaers.74.23.

[10] I. Hamdi, "New Normal, Pengunjung Ragunan dan Ancol Naik Dua Kali Lipat," Kompas, p. 3, Jun. 10, 2020.

[11] Bramantyo, "New Normal ala Kebun Binatang di Solo, Setiap Sesi Dibatasi 500 Orang Pengunjung," Oke Travel, p. 1, Jun. 18, 2020.
[12] Menteri Kesehatan RI, "Panduan Pencegahan Pengendalian COVID-19 di Perkantoran dan Industri." Pemerintah Republik Indonesia, Mei 2020.

[13] Bandung Zoo, "Masa Depan Kebun Binatang Bandung di Masa Pandemi," 2020. http:// www.bandung-zoo.com/berita/masa-depankebun-binatang-bandung-di-masa-pandemi. 
$\begin{array}{lll}\text { Majalah IImiah UNIKOM } & \text { Vol.18 No. } 2\end{array}$ 